\title{
Synthetic Betulin Derivatives Inhibit Growth of Glioma Cells In Vitro
}

\author{
SYLWIA K. KRÓL ${ }^{1}$, EWA BĘBENEK ${ }^{2}$, ADRIANNA SŁAWIŃSKA-BRYCH ${ }^{3}$, \\ MAGDALENA DMOSZYŃSKA-GRANICZKA ${ }^{1}$, STANISŁAW BORYCZKA ${ }^{2}$ and ANDRZEJ STEPULAK ${ }^{1}$ \\ ${ }^{1}$ Department of Biochemistry and Molecular Biology, Medical University, Lublin, Poland; \\ ${ }^{2}$ Department of Organic Chemistry, Medical University of Silesia, Katowice, Poland; \\ ${ }^{3}$ Department of Cell Biology, Maria Curie-Skłodowska University, Lublin, Poland
}

\begin{abstract}
Background/Aim: Glioma is the most malignant tumour of the human brain still lacking effective treatment modalities. Betulin, a pentacyclic triterpene abundantly found in the birch bark, has been shown to demonstrate interesting anticancer activity towards many cancer cells. We determined the effects of acetylenic synthetic betulin derivatives (ASBDs) as anti-tumour agents on glioma cells in vitro. Materials and Methods: T98G and C6 glioma cell viability and proliferation were determined by MTT (3-(4,5-dimethylthiazol-2-yl)-2,5diphenyl tetrazolium bromide) assay and BrdU (bromo deoxyuridine) test, respectively. Cell-cycle progression and induction of apoptosis were investigated with flow cytometry. Results: ASBDs significantly decreased glioma cell viability/survival and inhibited proliferation in a dose-dependent manner in vitro. Moreover, ASBDs were more cytotoxic than clinically used chemotherapeutics - temozolomide and cisplatin. Conclusion: ASBDs may be considered for further study as potent anti-tumour agents in glioma treatment.
\end{abstract}

Gliomas are the most common tumours of the central nervous system in adults and account for over $80 \%$ of brain malignancies. Among them, glioblastoma (GBM, WHO grade IV) is the most frequently diagnosed and most aggressive $(1,2)$. Characteristic features of GBM are intense cell proliferation, infiltrative and diffuse growth, high level of genetic and molecular heterogeneity. Its development is accompanied by extensive angiogenesis and resistance to

This article is freely accessible online.

Correspondence to: Sylwia K. Król, Ph.D., Department of Molecular and Translational Oncology, Maria Sklodowska-Curie National Research Institute of Oncology, Roentgena 5 street, 02781 Warsaw, Poland, Tel: +48 225462093, Fax: +48 225462093, e-mail: sylwia_krol15@wp.pl

Key Words: Acetylenic synthetic betulin derivatives, betulin, chemotherapy, glioma. standard therapy $(3,4)$. High-throughput analysis and largescale profiling of GBM cells have revealed frequent genetic dysfunction of tumour suppressors and oncogenes, and many epigenetic deregulations playing a pivotal role in pathogenesis and recurrence of $\operatorname{GBM}(5,6)$. Currently, available treatment is limited and includes surgical resection, followed by radiation and chemotherapy with temozolomide (TMZ), and only prolongs survival but is not curative (7).

Terpenes are a large class of secondary metabolites widely spread in plants (8). The broad range of their biological properties, including anti-oxidant, anti-bacterial, anti-viral, antifungal activities (9-11) and chemopreventive, anti-tumour potential have been shown (12-15). Betulin (BE, lup-20(29)ene-3 $\beta, 28$-diol) is a pentacyclic triterpenoid abundantly present in the birch bark of Betulaceae family. Several studies have found significant anti-cancer activity of $\mathrm{BE}$ in vitro and in vivo $(16,17)$. A key limitation for pharmacological effectiveness of $\mathrm{BE}$ (and other terpenes) is its poor solubility in aqueous solutions. Also, the structure of BE molecule enables chemical modifications and thus many of its derivatives with better solubility in water and bioavailability may be designed. That makes $\mathrm{BE}$ an interesting drug candidate and precursor for synthesis of new derivatives with potential application in oncology (18).

We have synthesised the series of novel betulin derivatives with acetylenic group (ASBDs) at C-3 and/or C-28 positions. Synthesis, structural analysis and detailed chemical characterisation have been described previously (19). In this study, we focused on anti-cancer effects of two ASBDs: 28-Opropynoylbetulin (EB5) and 28-O-propargyloxycarbonylbetulin (EB25/1) on glioma cells in vitro. Our findings showed a significant decrease of glioma cell viability and proliferation. We also found stronger cytotoxicity of ASBDs towards GBM cells than TMZ and cisplatin (CDDP).

\section{Materials and Methods}

Cell culture and treatment. Human GBM cell line T98G and rat glioma C6 were purchased from American Type Culture Collection 
(ATCC, Manassas, VA, USA). The cells were cultured in Dulbecco's-modified Eagles's medium (DMEM, Sigma-Aldrich, St. Louis, MO, USA) supplemented with $10 \%$ fetal bovine serum (FBS, Sigma-Aldrich, and antibiotics: $100 \mathrm{U} / \mathrm{ml}$ penicillin, $100 \mu \mathrm{g} / \mathrm{ml}$ streptomycin (Sigma-Aldrich). The cell cultures were maintained in standard conditions (20).

The ASBDs were synthesised in Department of Organic Chemistry at Medical University of Silesia in Katowice. ASBDs were dissolved in dimethyl sulfoxide (DMSO, Sigma-Aldrich) to prepare fresh stock solution before each experiment $(25 \mathrm{mM}$ for EB5 or $50 \mathrm{mM}$ for EB25/1). TMZ (temozolomide, Sigma-Aldrich) was dissolved in DMSO (stock solution $150 \mathrm{mM}$ ). CDDP (cisplatin, Sigma-Aldrich) was dissolved in PBS (stock solution $10 \mathrm{mM}$ ). To exclude any toxic effects of DMSO, the highest concentration of solvent was used as a control treatment.

MTT (3-(4,5-dimethylthiazol-2-yl)-2,5-diphenyl tetrazolium bromide) test. T98G and C6 cells were seeded on 96-well microplates at a density of $1.0 \times 10^{3}$ or $0.5 \times 10^{3}$ cells/well, respectively. Cell viability was determined after $96 \mathrm{~h}$ of exposure to increasing concentrations of ASBDs or DMSO (solvent control, CTRL) as described previously (21).

BrdU (bromo deoxyuridine) incorporation assay. Cell proliferation was determined using colorimetric immunoassay based on the measurement of BrdU incorporated into DNA strand during synthesis of DNA. T98G and C6 cells were seeded on 96-well microplates at a density of $1.0 \times 10^{3}$ or $0.5 \times 10^{3}$ cells/well, respectively and left overnight. Then, culture medium was removed and cells were exposed to selected concentrations of ASBDs or DMSO. Cell proliferation was assessed after $48 \mathrm{~h}$. Commercially available Cell Proliferation ELISA BrdU Kit (Roche Diagnostics $\mathrm{GmbH}$, Mannheim, Germany) was used according to manufacturer's protocol, the absorbance was measured at $450 \mathrm{~nm}$ wavelength using Microplate Reader TECAN Infinite M200 Pro (Tecan, Mannedorf, Switzerland) operating with Microplate Manager ver. 5 software.

Cell-cycle analysis. Cell-cycle progression was investigated by measurement of propidium iodide (PI) incorporated into DNA by flow cytometry. T98G and C6 cells were seeded on 6-well plates at a density of $5.0 \times 10^{5}$ or $1.5 \times 10^{5}$ cells/well, respectively and left overnight. Then, culture medium was removed and cells were exposed for $24 \mathrm{~h}$ to selected concentrations of ASBDs or DMSO, and the procedure was performed as described previously (22). Nocodazole $(5 \mu \mathrm{g} / \mathrm{ml})$ was used as a reference drug inducing $\mathrm{G}_{2} / \mathrm{M}$ cell-cycle arrest, showing functional assay.

Assessment of apoptosis. Determination of apoptosis was based on the detection of active caspase 3 in glioma cells by flow cytometry. T98G and C6 cells were seeded on 6-well plates at a density of $5.0 \times 10^{5}$ or $1.5 \times 10^{5}$ cells/well, respectively and left overnight. Then, the culture medium was removed and cells were exposed to selected concentrations of ASBDs or DMSO. The cells were harvested with accutase after $24 \mathrm{~h}$ of treatment with ASBDs, centrifuged at $300 \times \mathrm{g}$ for $5 \mathrm{~min}$ at $+4^{\circ} \mathrm{C}$ and washed twice with PBS. Camptothecin $(20 \mu \mathrm{M})$ was used as a reference drug inducing apoptosis. Commercially available PE Active Caspase-3 Apoptosis Kit (BD Pharmingen ${ }^{\mathrm{TM}}$, BD Biosciences, San Diego, CA, USA) was used according to manufacturer's protocol and cells were analysed by flow cytometer FACSCalibur (Becton Dickinson, San Jose, CA, USA), operating with CellQuest software.
Statistical analysis. Results are present as means \pm standard error of the mean (SEM). Statistical significance was determined by one-way or two-way ANOVA with Tukey's or Dunnett's post hoc test using GraphPad Prism ver. 6 (GraphPad Software, San Diego, CA, USA).

\section{Results}

In our study, the series of new ASBDs with acetylenic pharmacophores at C-28 position were tested to reveal their anti-cancer activities in vitro. Chemical structures of precursor BE molecule and synthesized ASBDs: 28-O-propynoylbetulin (EB5) and 28-O-propargyloxycarbonylbetulin (EB25/1) are shown in Figure 1.

ASBDs reduce viability and inhibit proliferation of glioma cells. We observed a significant decrease of cell viability (Figure 2A and $\mathrm{B}$ ) and cell proliferation (Figure 2C and D) in T98G and C6 cells after treatment with ASBDs in a dose-dependent manner. When comparing both compounds, EB5 exerted enhanced cytotoxic effect towards both glioma cell lines than EB25/1, whereas T98G cells (Figure 2A and C) were less sensitive to ASBDs treatment than C6 cells (Figure 2B and D). Interestingly, in our experimental settings TMZ, used as standard therapy for GBM patients, revealed an inhibitory effect on glioma cell viability at much higher concentrations (over 200 $\mu \mathrm{M})$ when compared to EB5 or EB25/1 (10-25 $\mu \mathrm{M})$, showing therapeutic potential of tested ASBDs (Figure 2A and B).

ASBDs applied in combination with CDDP augment cytotoxicity of each drug administered separately. CDDP has been recently considered as potentially useful in the treatment of human GBM $(23,24)$. Therefore, we evaluated the effect of combined treatment with ASBDs and CDDP in glioma cells by MTT testing (Figure 3). First, we assessed $\mathrm{IC}_{50}$ values (a concentration inhibiting the survival of $50 \%$ of treated cells when compared to untreated) for tested compounds (Table I). Glioma cell lines showed differential response to CDDP in monotherapy. T98G cells were moderately sensitive $\left(\mathrm{IC}_{50}=17.63 \mu \mathrm{M}\right)$ (Figure $\left.3 \mathrm{~A}\right)$, while sensitivity of C6 cells was much more pronounced $\left(\mathrm{IC}_{50}=2.31 \mu \mathrm{M}\right)$ (Figure $3 \mathrm{C}$ ). Combination of EB5 or EB25/1 with $\mathrm{CDDP}$ at $\mathrm{IC}_{50}$ values decreased T98G cells viability to a greater extent than treatment with all tested compounds applied separately (Figure 3B). Similarly, when C6 cells were exposed to combination of EB5 and CDDP, the viability of C6 cells was significantly reduced in comparison to single treatment. In contrast, combination of EB25/1 and CDDP did not reveal such an effect in this particular cell line (Figure 3D).

ASBDs inhibit cell-cycle progression and induce apoptosis in glioma cells. We observed a statistically significant reduction in percentage of $\mathrm{T} 98 \mathrm{G}$ cells in $\mathrm{G}_{1}$ phase, accompanied by increase in cell number in $S$ phase after the treatment with the highest concentration $(25 \mu \mathrm{M})$ of both ASBDs (Figure 4A). In 

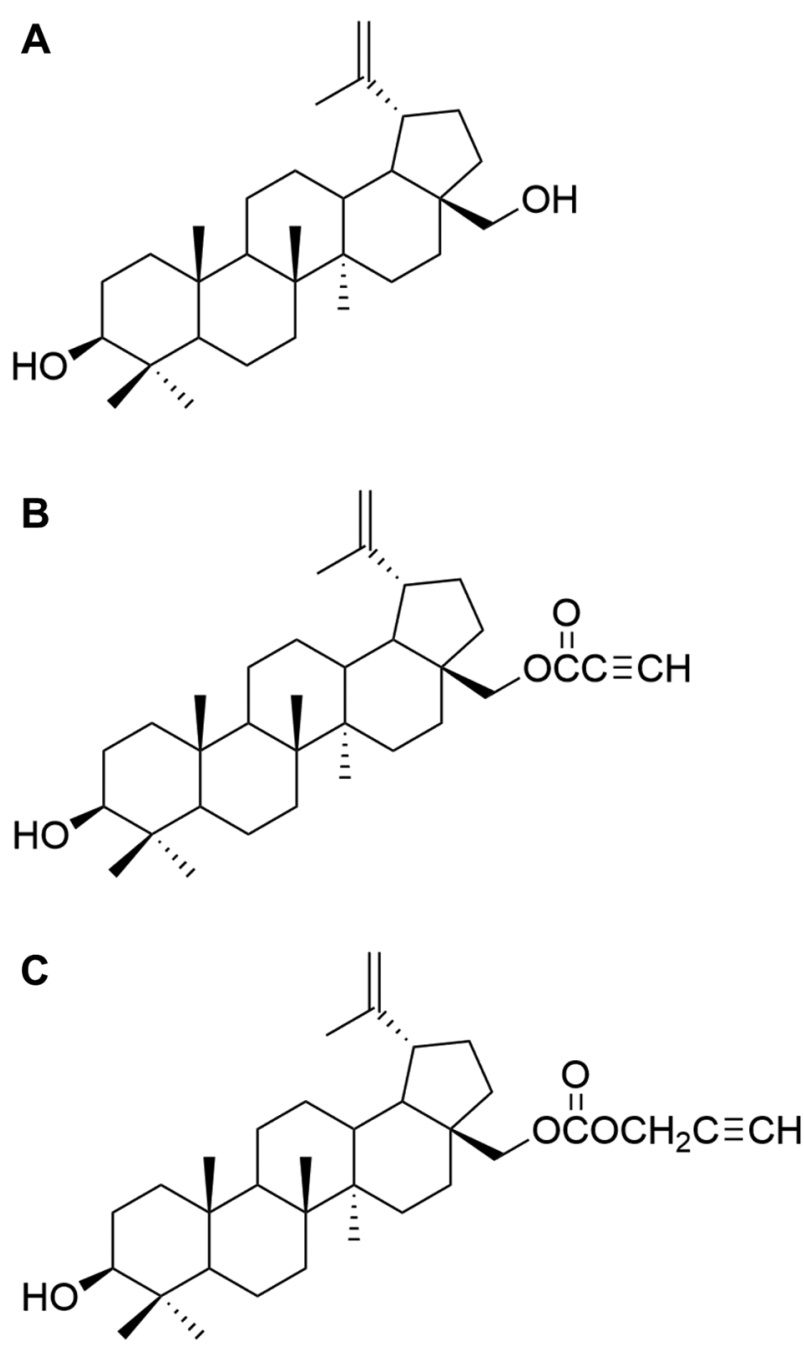

Figure 1. Chemical structure of $B E$ and its acetylenic synthetic derivatives (ASBDs). Betulin (A), 28-O-propynoylbetulin (B) and 28-Opropargyloxycarbonylbetulin $(C)$.

contrast, decrease in number of $\mathrm{C} 6$ cells in $\mathrm{G}_{1}$ and $\mathrm{S}$ phase with simultaneous rise of cell percentage in $G_{2} / M$ phase was found, and the effect was statistically significant at the 20-25 $\mu \mathrm{M}$ concentrations of EB5 (Figure 4C), suggesting a different, cell type-dependent mechanism of cell-cycle inhibition.

Further, we analysed whether cytotoxicity and antiproliferative effects of ASBDs on glioma cells were due to activation of apoptosis. Thus, detection of active caspase 3 in tumour cells by flow cytometry was performed. Interestingly, we found no significant induction of caspase 3 after $24 \mathrm{~h}$ of treatment with both ASBDs in T98G cells (Figure 4B). In contrast, significant activation of caspase 3 was observed in C6 cells exposed to EB5, but not EB25/1 and the effect was dose-dependent (Figure 4D).

\section{Discussion}

Despite significant advances in surgical procedures, radioand chemotherapy and growing knowledge of genetic and molecular background of gliomas during the last years, prognosis for GBM patients still remains poor with an overall survival of 12.1-14.6 months after diagnosis (4). Therefore, there is an urgent need for development of more effective and targeted therapy of patients with malignant gliomas.

The use of natural plant-derived compounds has been considered as an interesting and promising approach for prevention and treatment of many human diseases, including cancer. BE has been shown to possess a wide spectrum of anti-cancer activity in vitro and in vivo, as previously demonstrated by our group $(16,17)$ and others $(25-27)$. Since the structure of $\mathrm{BE}$ molecule enables several chemical modifications, BE has been used as a precursor for the synthesis of many new derivatives with prospective application in chemotherapy (28-31).

In this paper, we demonstrated the anti-cancer activity of two ASBDs: 28-O-propynoylbetulin (EB5) and 28-Opropargyloxycarbonylbetulin (EB25/1) against glioma cells in vitro. In our research, the concentrations of studied ASBDs required to exert significant cytotoxic and antiproliferative effects (the values of $\mathrm{IC}_{50}<25 \mu \mathrm{M}$ for T98G as well C6 cells) were much lower than concentrations of TMZ (the $\mathrm{IC}_{50}$ values $>200 \mu \mathrm{M}$ for $\mathrm{C} 6$ and $>800 \mu \mathrm{M}$ for $\mathrm{T} 98 \mathrm{G}$ cells), which is commonly used for glioma patients treatment. Considering the above, our study opens new fields of investigation for development of new promising anticancer drugs. Besides, combination of ASBDs and CDDP (at the doses of $\mathrm{IC}_{50}$ values) affected glioma cells viability at a greater extent than ASBDs applied singly, showing their potential use for development of new therapeutic protocols in combination with cisplatin. Our findings were highly concordant with previous reports showing higher cytotoxic activity of EB5 than CDDP in human and murine leukaemia cell lines in vitro (19). Although anti-cancer activity of tested ASBDs was evident, the molecular mechanism responsible for observed phenomena was not resolved and requires further studies. It seems, that inhibition of the cell-cycle progression was cell-type dependent, thereby more advanced studies are required (e.g. RNA sequencing), in order to decipher genetic or epigenetic differences in analysed cell lines, which are responsible for diverse responses of these glioma cells for ASBDs treatment. Similarly, no induction of apoptosis (by means of lack or very low level of active caspase 3) may suggest triggering of another programmed cell death after treatment with ASBDs, which could be also cell type- or compound-dependent. In melanoma cells exposed to EB5, two-fold and nine-fold increase of caspase 3 activation was found in comparison to the same concentration of BE and to control cells, respectively (28). 
A

T98G
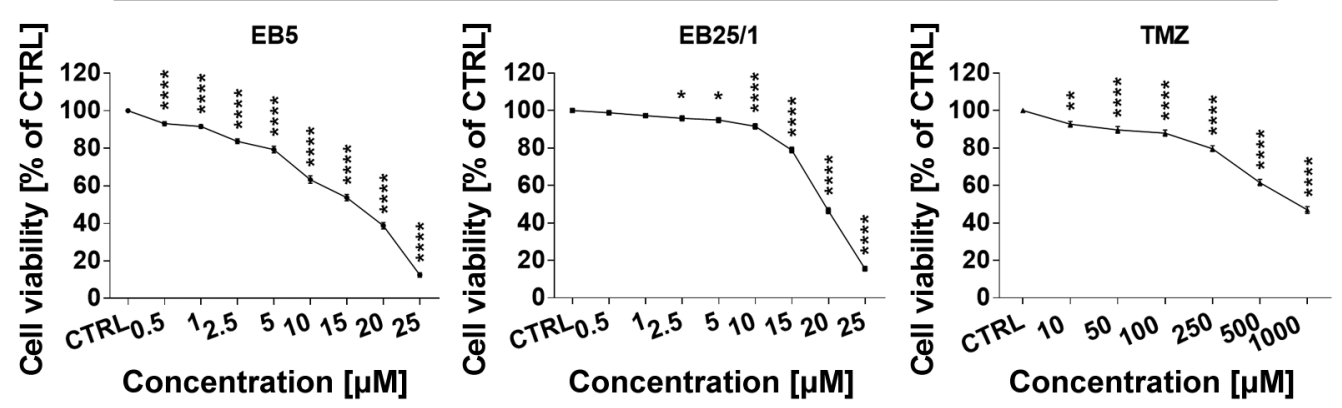

B

C6
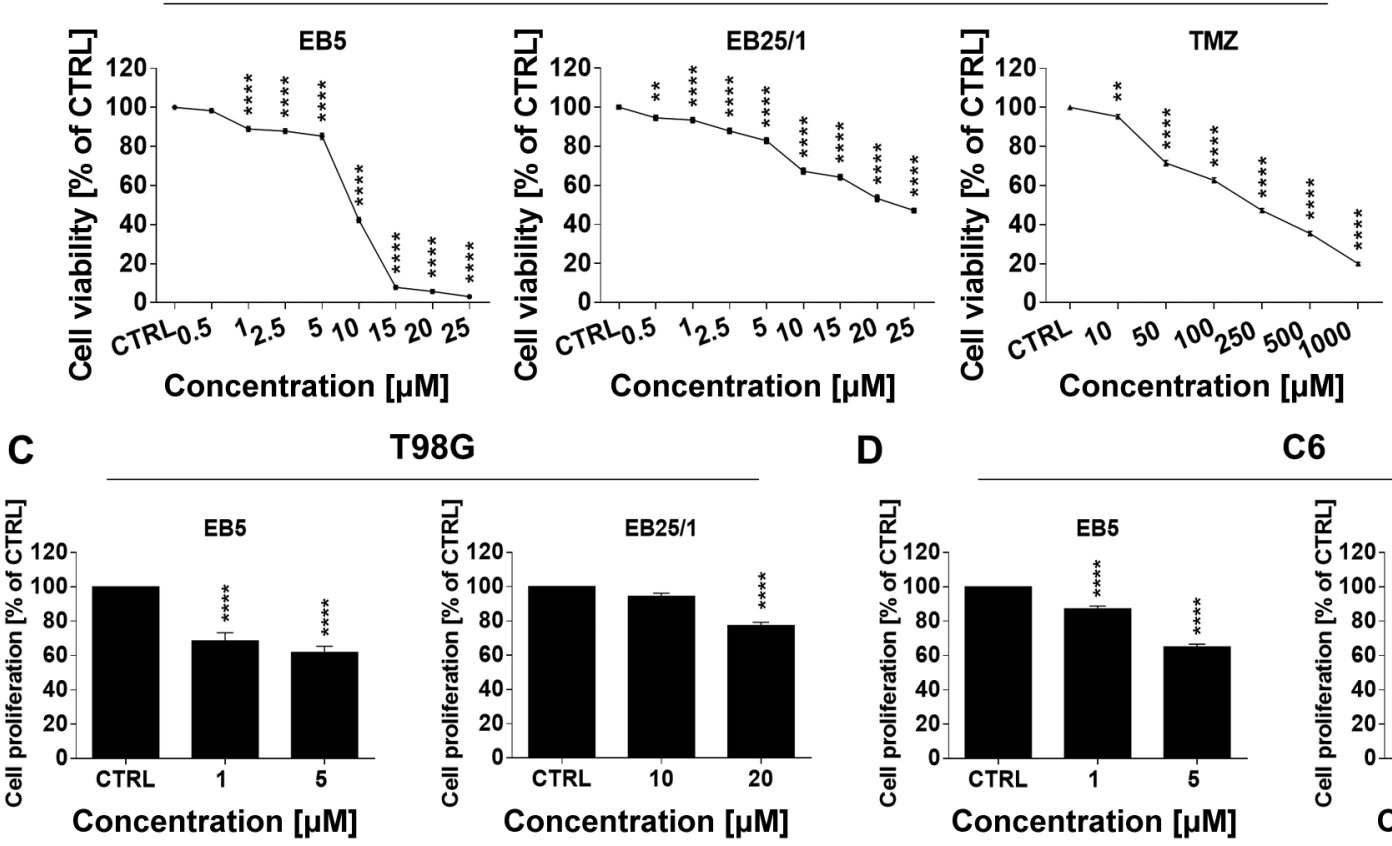

T98G

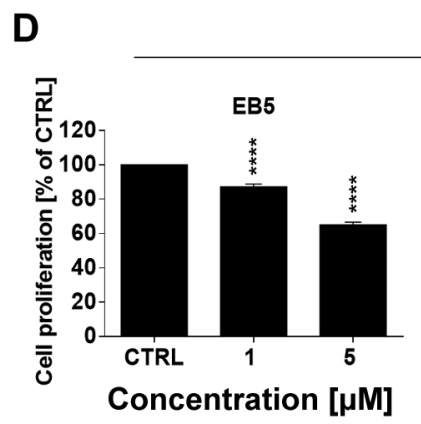

C6
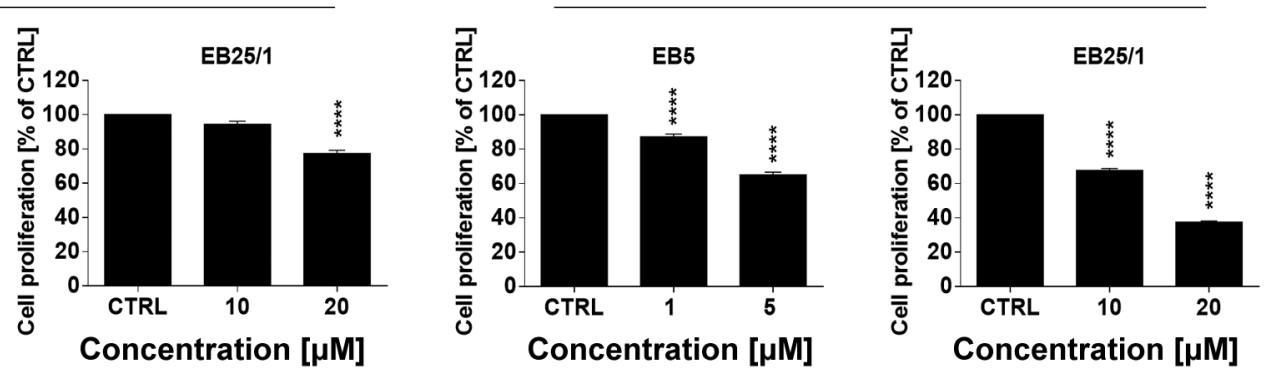

Figure 2. ASBDs reduce viability and inhibit proliferation of glioma cells in vitro. T98G $(A)$ and C6 (B) cell lines were treated with ASBDs or TMZ (as a reference drug) for $96 \mathrm{~h}$ and assessed for cell viability by MTT test. T98G (C) and C6 (D) cells were exposed to ASBDs for $48 \mathrm{~h}$ and cell proliferation was analysed by BrdU assay. The results were normalized to control cells (CTRL, $0.1 \%$ DMSO) and represent the mean \pm SEM of $n=32$ from 4 independent experiments or $n=24$ samples from 3 independent experiment for MTT assay and BrdU test, respectively. Statistical significance was determined by one-way ANOVA with Dunnett's multiple comparisons post hoc test. *p $\leq 0.05, * * p \leq 0.01, * * * p \leq 0.001, * * * * p \leq 0.0001$.

Relative to BE, differences in chemical structure of EB5 and EB25/1 have undoubtedly determined their biological properties. The introduction of acetyl substituent (e.g. propynoyl) containing carbon-carbon triple bond into the $\mathrm{BE}$ molecule seems to be essential for its biological activity and enhances anti-cancer potential. This structural modification at the C-28 position close to the carbonyl group, results in formation of configuration with relatively high reactivity, which may easily interact with other ligands and molecules. Consequently, it is considered that alkyne groups at the C28 augment the affinity to the nucleophilic amine or thiol
Table I. Cytotoxic activity of CDDP, TMZ and ASBDs by means of $I C_{50}$ values.

\begin{tabular}{lrrrr}
\hline Cell line & \multicolumn{4}{c}{ IC $_{50}$} \\
\cline { 2 - 5 } & \multicolumn{1}{c}{ CDDP } & TMZ & \multicolumn{1}{c}{ EB5 } & EB25/1 \\
\hline T98G & $17.63 \mu \mathrm{M}$ & $895.55 \mu \mathrm{M}$ & $16.23 \mu \mathrm{M}$ & $19.46 \mu \mathrm{M}$ \\
C6 & $2.31 \mu \mathrm{M}$ & $222.67 \mu \mathrm{M}$ & $9.11 \mu \mathrm{M}$ & $22.68 \mu \mathrm{M}$ \\
\hline
\end{tabular}

CDDP: Cisplatin, cis-diamminedichloridoplatinum(II); TMZ: temozolomide; ASBDs: acetylenic synthetic betulin derivatives (EB5, EB25/1); $\mathrm{IC}_{50}$ : half maximal inhibitory concentration. 
A

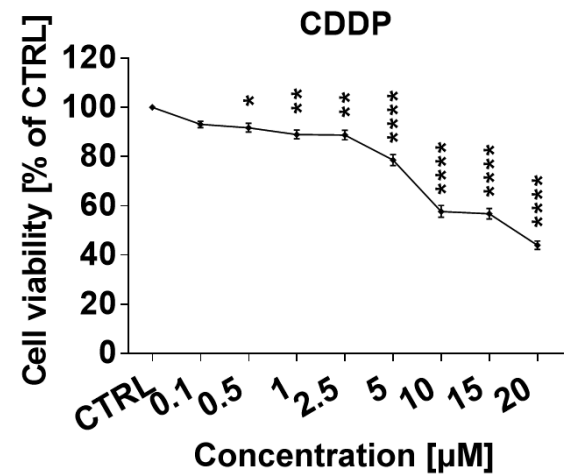

C

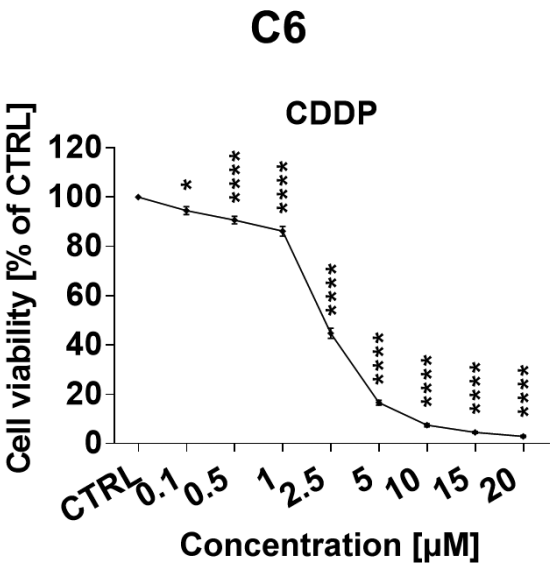

T98G
B

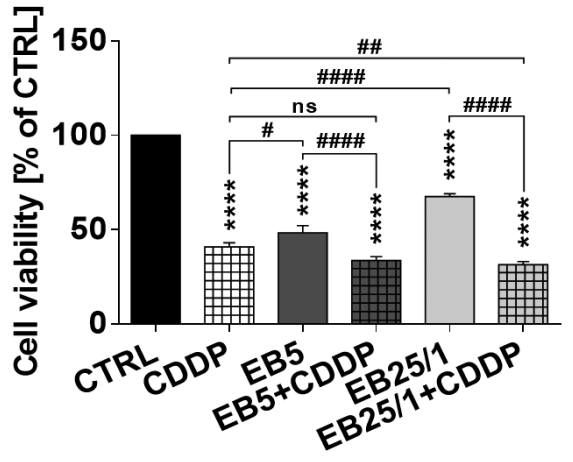

D

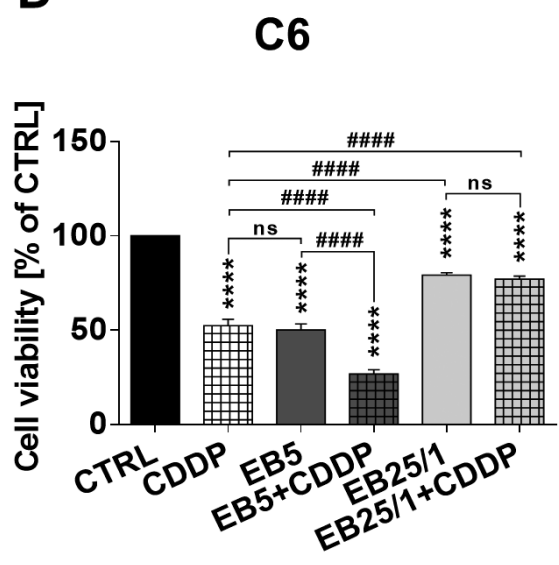

Figure 3. ASBDs in combination with CDDP reduce viability of glioma cells in vitro. T98G cells were exposed to CDDP alone (A), and combination of $A S B D$ s with $C D D P$ (the doses of $\left.I C_{50}\right)(B)$ for $96 \mathrm{~h}$ and assessed for cell viability by MTT. C6 cells were exposed to CDDP alone (C), and combination of $A S B D$ s with $C D D P$ (the doses of $\left.I C_{50}\right)(D)$ for $96 \mathrm{~h}$ and assessed for cell viability by MTT. The results were normalized to control cells (CTRL; $0.1 \%$ of PBS or $0.1 \%$ of DMSO) and represent the mean \pm SEM of $n=24$ samples from 3 independent experiments. Statistical significance was determined by one-way ANOVA with Dunnett's $(A, C)$ or Tukey's $(B, D)$ multiple comparisons post hoc test. ${ }^{*} p \leq 0.05, * * p \leq 0.01, * * * p \leq 0.001$, $* * * * p \leq 0.0001$ and ${ }^{\#} p \leq 0.05,{ }^{\# \#} p \leq 0.01, \# \# \# \# \leq 0.0001$.

groups of proteins in the cellular membranes affecting their integrity and stability and thus decreasing cell viability and survival $(28,29)$. Moreover, EB5, a BE derivative having a shorter alkynyl chain, was found to be more toxic to the studied cell lines than EB25/1 (by means of lower $\mathrm{IC}_{50}$ values) and these results are consistent with previous in vitro data concerning human colorectal adenocarcinoma (SW707 cell line), leukaemia (CCRF/CEM), breast cancer (T47D) and murine leukaemia (P388) (19).

\section{Conclusion}

ASBDs may be considered as potential agents in chemotherapy - in monotherapy, as well as combination with routinely used cytostatics (such as CDDP). Collectively, our findings may be useful in designing a structure of new therapeutic chemicals and derivatives of $\mathrm{BE}$ and other natural compounds potentially relevant in clinical oncology. The cytotoxic and antiproliferative potential of ASBDs on glioma cells in vitro has to be more carefully studied. Another interesting aspect of potential usefulness of ASBDs in oncology could be their application in combination with TMZ. Revealing the mechanism of ASBDs activity (e.g. pathways of cell death) may become a starting point for further in vivo study and support development of new anti-glioma chemotherapeutics. Genetic and molecular background of studied tumour cell lines treated with ASBDs should also be analysed in details (e.g. RNA sequencing) to determine detailed mechanism of action 
A

T98G

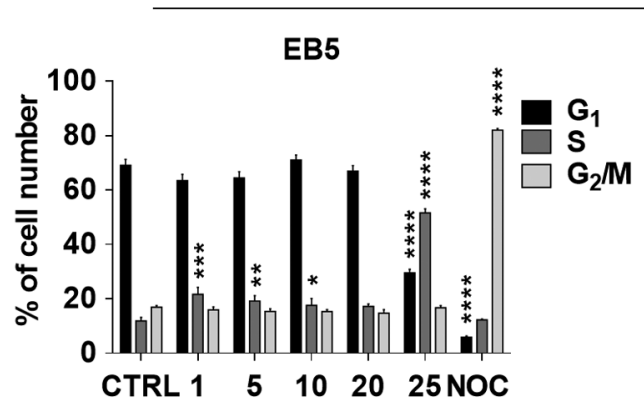

Concentration $[\mu \mathrm{M}]$

B

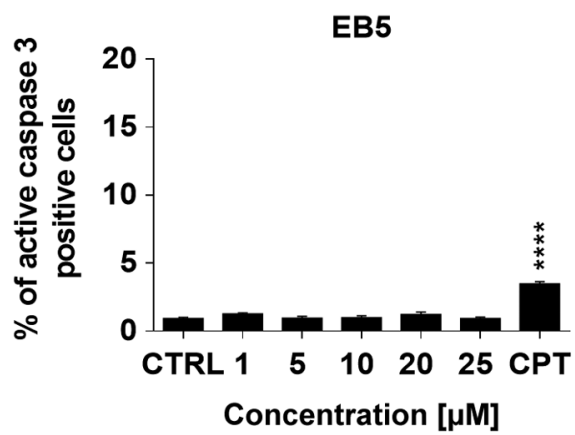

C

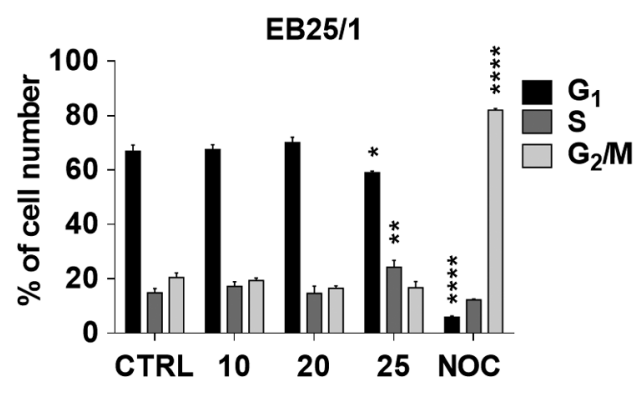

Concentration $[\mu \mathrm{M}]$

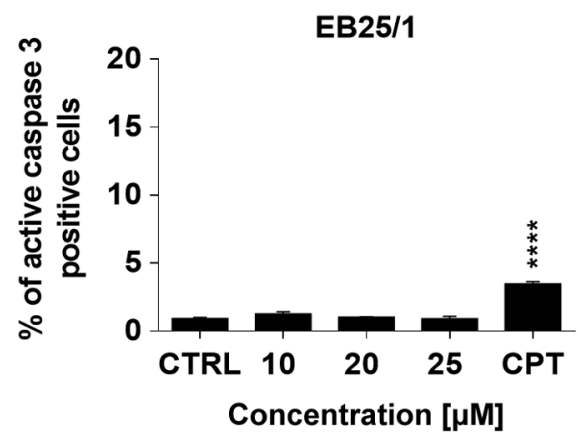

C6

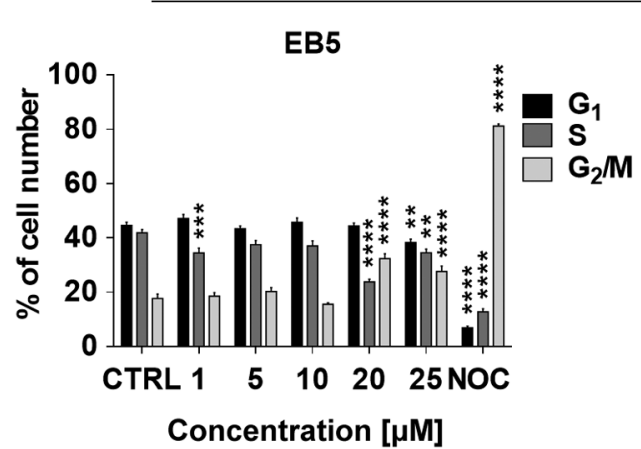

D

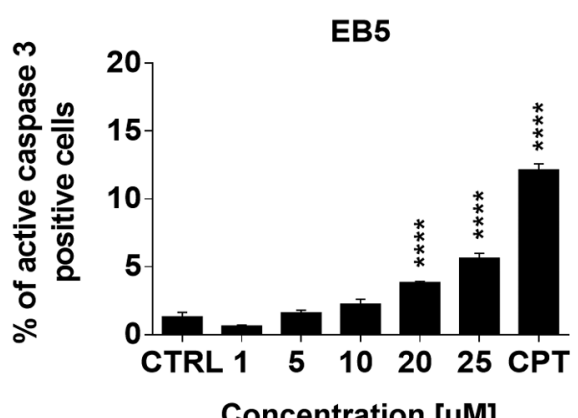

Concentration $[\mu \mathrm{M}]$

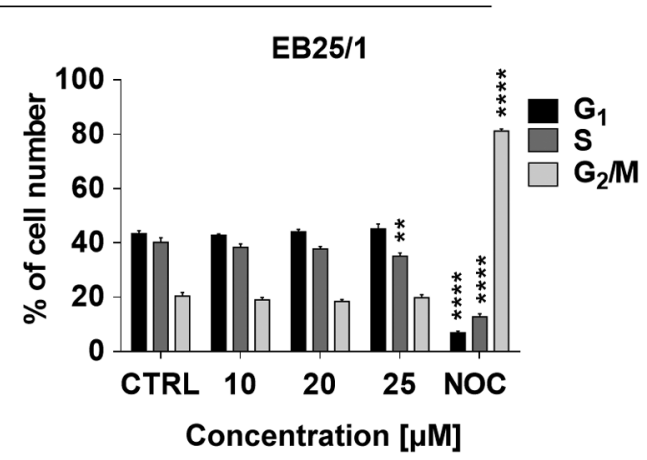

Concentration $[\mu \mathrm{M}]$

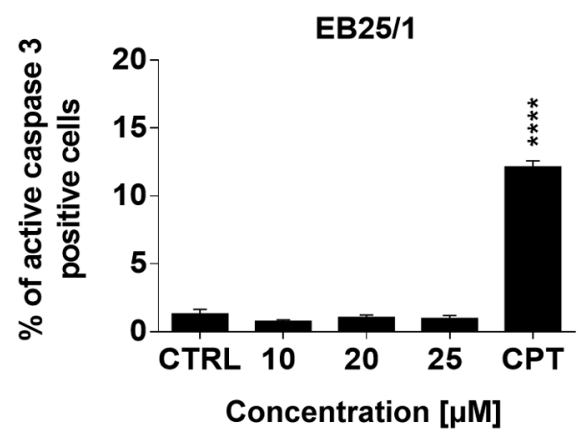

Figure 4. ASBDs inhibit cell-cycle progression and induce apoptosis in glioma cells in vitro. T98G cells (A) and C6 cells (C) were analysed with flow cytometry for cell-cycle progression. Activation of caspase 3 after treatment with ASBDs for $24 \mathrm{~h}$ in T98G cells $(B)$ and C6 cells $(D)$ is shown. Nocodazole $(\mathrm{NOC}, 5 \mathrm{\mu g} / \mathrm{ml})$ and camptothecin $(C P T, 20 \mu \mathrm{M})$ were used as reference drugs. Control cells $(C T R L)$ were treated with $0.1 \%$ DMSO. The results represent the mean $\pm S E M$ of $n=10$ samples from 5 independent experiments. Statistical significance was determined by one-way $(B, D)$ or two-way $(A, C)$ ANOVA with Dunnett's multiple comparisons post hoc test. *p $\leq 0.05, * * p \leq 0.01, * * * p \leq 0.001$, ****p $\leq 0.0001$. 
of these compounds. Next, translational studies analysing genetic background of glioma tumors could define groups of patients that may potentially benefit the most from prospective therapy with ASBDs. Summing up, the results presented in this paper are preliminary, but promising and providing support for further study of ASBDs in preclinical cancer models in single treatment as well as in combination therapy.

\section{Conflicts of Interest}

The Authors declare no conflicts of interest.

\section{Authors' Contributions}

Conception and design of the study: SKK, AS. Methodology and investigation: SKK, EB, AS-B, MD-G. Data analysis and interpretation: SKK, AS. Study supervision: AS. Writing - original draft and figures: SKK. Writing - review and editing: EB, SB, AS. All Authors have read and approved the final version of the manuscript.

\section{Acknowledgements}

This study was supported by DS440 grant founded by Medical University in Lublin. The authors thank Agnieszka Styczyńska for the editorial assistance and proofreading.

\section{References}

1 Ostrom QT, Bauchet L, Davis FG, Deltour I, Fisher JL, Langer CE, Pekmezci M, Schwartzbaum JA, Turner MC, Walsh KM, Wrensch MR and Barnholtz-Sloan JS: The epidemiology of glioma in adults: a "state of the science" review. Neuro Oncol 16(7): 896-913, 2014. PMID: 24842956. DOI: 10.1093/neuonc/ nou087

2 Tamimi AF and Juweid M: Epidemiology and outcome of glioblastoma. In: Glioblastoma. De Vleeschouwer S (ed.). Brisbane, Codon Publications, pp. 143-153, 2017. PMID: 29251870. DOI: 10.15586/codon.glioblastoma.2017.ch8

3 Soeda A, Hara A, Kunisada T, Yoshimura SI, Iwama T and Park DM: The evidence of glioblastoma heterogeneity. Sci Rep 5(1): 7979, 2015. PMID: 26010816. DOI: 10.1038/srep09630

4 Bianco J, Bastiancich C, Jankovski A, des Rieux A, Préat V and Danhier F: On glioblastoma and the search for a cure: where do we stand? Cell Mol Life Sci 74(13): 2451-2466, 2017. PMID: 28210785. DOI: $10.1007 / \mathrm{s} 00018-017-2483-3$

5 Was H, Król SK, Rotili D, Mai A, Wojtas B, Kaminska B and Maleszewska M: Histone deacetylase inhibitors exert anti-tumor effects on human adherent and stem-like glioma cells. Clin Epigenet 11(1): 1-13, 2019. PMID: 30654849. DOI: 10.1186/ s13148-018-0598-5

6 Kaminska B, Czapski B, Guzik R, Król SK and Gielniewski B: Consequences of IDH1/2 mutations in gliomas and an assessment of inhibitors targeting mutated IDH proteins. Molecules 24(5): 968-984, 2019. PMID: 30857299. DOI: $10.3390 /$ molecules 24050968

7 Anjum K, Shagufta BI, Abbas SQ, Patel S, Khan I, Shah SA A and Ul Hassan SS: Current status and future therapeutic perspectives of glioblastoma multiforme (GBM) therapy: a review. BioMed Pharmacother 92: 681-689, 2017. PMID: 28582760. DOI: 10.1016/j.biopha.2017.05.125

8 Ahmed E, Arshad M, Khan MZ, Amjad HS, Sadaf HM, Riaz I and Sabaoon MA: Secondary metabolites and their multidimensional prospective in plant life. J Pharmacogn Phytochem 6(2): 205-214, 2017.

9 Bakkali F, Averbeck S, Averbeck D and Idaomar M: Biological effect of essentials oils - a review. Food Chem Toxicol 46(2): 446475, 2008. PMID: 17996351. DOI: 10.1016/j.fct.2007.09.106

10 Król SK and Kapka-Skrzypczak L: Aktywność farmakologiczna olejków eterycznych i ich składników w leczeniu schorzeń układu pokarmowego. Med Og Nauk Zdr 17(4): 202-205, 2011.

11 Król SK, Skalicka-Woźniak K, Kandefer-Szerszeń M and Stepulak A: Aktywność biologiczna i farmakologiczna olejków eterycznych w leczeniu i profilaktyce chorób infekcyjnych. Post Hig i Med Dośw 67: 1000-1007, 2013. PMID: 24088544. DOI: 10.5604/17322693.1067687

12 Paduch R, Trytek M, Król SK, Kud J, Frant M, Kandefer-Szerszeń $\mathrm{M}$ and Fiedurek J: Biological activity of terpene compounds produced by biotechnological methods. Pharm Biol 54(6): 10961107, 2016. PMID: 26808720. DOI: 10.3109/13880209.2015. 1103753

13 Rzeski W, Stepulak A, Szymański M, Sifringer M, Kaczor J, Wejksza K and Kandefer-Szerszeń M: Betulinic acid decreases expression of bcl-2 and cyclin D1, inhibits proliferation, migration and induces apoptosis in cancer cells. NaunynSchmiedeberg's Arch Pharmacol 374(1): 11-20, 2006. PMID: 16964520. DOI: 10.1007/s00210-006-0090-1

14 Nirmala MJ, Samundeeswari A and Sankar PD: Natural plant resources in anti-cancer therapy - A review. Res Plant Biol 1(3): 1-14, 2011.

15 Huang M, Lu JJ, Huang MQ, Bao JL, Chen XP and Wang YT: Terpenoids: natural products for cancer therapy. Expert Opin Investig Drugs 21(12): 1801-1818, 2012. PMID: 23092199. DOI: $10.1517 / 13543784.2012 .727395$

16 Rzeski W, Stepulak A, Szymański M, Juszczak M, Grabarska A, Sifringer M, Kaczor J and Kandefer-Szerszeń M: Betulin elicits anti-cancer effects in tumour primary cultures and cell lines in vitro. Basic Clin Pharmacol Toxicol 105(6): 425-432, 2009. PMID: 19821831. DOI: 10.1111/j.1742-7843.2009.00471.x

17 Król SK, Kiełbus M, Rivero-Müller A and Stepulak A: Comprehensive review on betulin as a potent anticancer agent. Biomed Res Int 2015: 584189, 2015. PMID: 25866796. DOI: $10.1155 / 2015 / 584189$

18 Drąg-Zalesińska M and Borska S: Betulin and its derivativesprecursors of new drugs. World Sci News 127(3): 123-138, 2019.

19 Boryczka S, Bębenek E, Wietrzyk J, Kempińska K, Jastrzębska M, Kusz J and Nowak M: Synthesis, structure and cytotoxic activity of new acetylenic derivatives of betulin. Molecules 18(4): 45264543, 2013. PMID: 23595090. DOI: 10.3390/molecules 18044526

20 Sławińska-Brych A, Król SK, Dmoszyńska-Graniczka M, Zdzisińska B, Stepulak A and Gagoś M: Xanthohumol inhibits cell-cycle progression and proliferation of larynx cancer cells in vitro. Chem Biol Interact 240: 110-118, 2015. PMID: 26297991. DOI: 10.1016/j.cbi.2015.08.008

21 Jarząb A, Grabarska A, Kiełbus M, Jeleniewicz W, DmoszyńskaGraniczka M, Skalicka-Woźniak K, Sieniawska E, Polberg K and Stepulak A: Osthole induces apoptosis, suppresses cell-cycle progression and proliferation of cancer cells. Anticancer Res 34(11): 6473-6480, 2014. PMID: 25368248. 
22 Kiełbus M, Skalicka-Woźniak K, Grabarska A, Jeleniewicz W, Dmoszyńska-Graniczka, M, Marston A, Polberg K, Gawda P, Klatka J and Stepulak A: 7-substituted coumarins inhibit proliferation and migration of laryngeal cancer cells in vitro. Anticancer Res 33(10): 4347-4356, 2013. PMID: 24123002.

23 Basso U, Reni M, Vastola F, Tosoni A, Cavallo G, Scopece L, Ferreri AJ, Panucci MG, Monfardini S and Ermani M: First-line chemotherapy with cisplatin plus fractionated temozolomide in recurrent glioblastoma multiforme: a phase II study of the Gruppo Italiano Cooperativo di Neuro-Oncologia. J Clin Oncol 22(9): 15981604, 2004. PMID: 15117981. DOI: 10.1200/JCO.2004.11.019

24 Wang Y, Kong X, Guo Y, Wang R and Ma W: Continuous doseintense temozolomide and cisplatin in recurrent glioblastoma patients. Medicine (Baltimore) 96(10): e6261, 2017. PMID: 28272232. DOI: 10.1097/MD.0000000000006261

25 Zhanataev AK, Presnova GA, Chistyakov AN and Durnev AD: Effect of Betula bark extract on spontaneous and induced mutagenesis in mice. Bull Exp Biol Med 138(5): 475-478, 2004. PMID: 15723130. DOI: 10.1007/s10517-005-0074-z

26 Ciurlea SA, Tiulea C, Csanyi E, Csanyi E, Berko S, Toma CC, Dehelean CA and Loghin F: A pharmacotoxicological evaluation of a betulin topical formulation tested on C57BL/6J mouse experimental nevi and skin lesions. Stud Univ Vasile Goldis Arad Ser Stiint Vietii 20(4): 5-9, 2010.

27 Dehelean CA, Feflea S, Gheorgheosu D, Ganta S, Cimpean AM, Muntean D and Amiji MM: Antiangiogenic and anti-cancer evaluation of betulin nanoemulsion in chicken chorioallantoic membrane and skin carcinoma in Balb/c mice. J Biomed Nanotechnol 9(4): 577-589, 2013. PMID: 23621016. DOI: $10.1166 /$ jbn. 2013.1563
28 Orchel A, Kulczycka A, Chodurek E, Bębenek E, Borkowska, Boryczka S, Kowalski J and Dzierżewicz Z: Influence of betulin and 28-O-propynoylbetulin on proliferation and apoptosis of human melanoma cells (G-361). Post Hig i Med Dośw 68: 191197, 2014. PMID: 24662787. DOI: 10.5604/17322693.1088757

29 Bębenek E, Kadela-Tomanek M, Chrobak E, Wietrzyk J, Sadowska J and Boryczka S: New acetylenic derivatives of betulin and betulone, synthesis and cytotoxic activity. Med Chem Res 26(1): 1-8, 2017. PMID: 28111514. DOI: 10.1007/s00044-016$1713-9$

30 Drąg-Zalesińska M, Wysocka T, Borska S, Drąg M, Poręba M, Choromańska A, Kulbacka J and Saczko J: The new esters derivatives of betulin and betulinic acid in epidermoid squamous carcinoma treatment - In vitro studies. Biomed Pharmacother 72: 91-97, 2015. PMID: 26054680. DOI: 10.1016/j.biopha.2015.04.003

31 Drąg-Zalesińska M, Drąg M, Poręba M, Borska S, Kulbacka J and Saczko J: Anticancer properties of ester derivatives of betulin in human metastatic melanoma cells (Me-45). Cancer Cell Int 17(4): 1-7, 2017. PMID: 28053599. DOI: 10.1186/s12935-016-0369-3

Received August 11, 2020

Revised September 3, 2020

Accepted September 7, 2020 